\title{
Evaluation of wound-healing potency of Vernonia arborea Hk.
}

\author{
B. K. Manjunatha S. M. Vidya, K.V. Rashmi, K.L. Mankani', H.J. Shilpa, S.D. Jagadeesh Singh
}

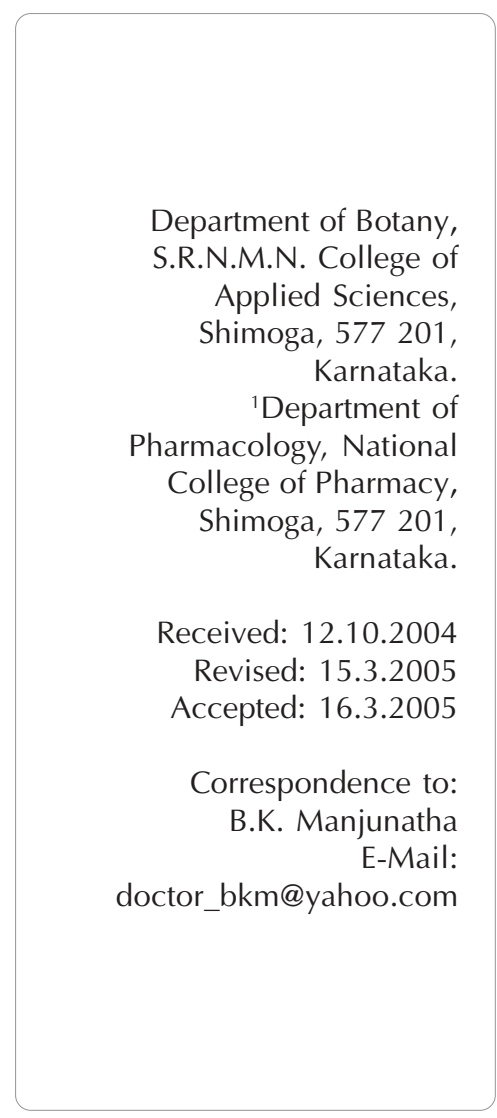

\begin{abstract}
Objective: To investigate the comparative wound-healing potency of aqueous and methanol leaf extracts of Vernonia arborea Hk.

Materials and Methods: Excision, incision and dead space wound models were used to evaluate the wound-healing activity of Vernonia arborea Hk., on Swiss Wistar strain rats of either sex. In excision wound model, treatment was continued till the complete healing of the wound, in incision and dead space wound models the treatment was continued for 10 days. For topical application, $5 \% \mathrm{w} / \mathrm{w}$ ointment of aqueous and methanol leaf extracts was prepared in $2 \%$ sodium alginate and for oral administration suspensions containing $30 \mathrm{mg} / \mathrm{ml}$ of each of the extracts in $1 \%$ gum tragacanth were prepared. In excision and incision wound models, the control group of animals were left untreated and in dead space wound models the animals were treated with $1 \mathrm{ml}$ of $1 \%$ gum tragacanth $/ \mathrm{kg}$, b.w. The healing of the wound was assessed by the rate of wound contraction, period of epithelialisation, skin breaking strength, granulation strength, dry granulation tissue weight, hydroxyproline estimation and histopathology of the granulation tissue.

Results: Aqueous and methanol leaf extracts promoted the wound-healing activity significantly in all the wound models studied. High rate of wound contraction, decrease in the period for epithelialisation, high skin breaking strength and granulation strength, increase in dry granulation tissue weight, elevated hydroxyproline content and increased collagenation in histopathological section were observed in animals treated with methanol leaf extract and aqueous leaf extract when compared to the control group of animals. Conclusion: Methanol and aqueous leaf extracts of Vernonia arborea Hk. promote woundhealing activity. Methanol extract possesses better wound-healing property than the aqueous extract.
\end{abstract}

KEY WORDS: Skin breaking strength, wound contraction, wound models.

\section{Introduction}

The plant Vernonia arborea Hk. is a moderate sized tree belonging to the family Asteraceae. It is distributed in the coastal districts of Karnataka State, especially in the South Canara district. ${ }^{[1]}$ The plant has many medicinal properties viz., leaf juice is used to treat worms, infusion of roots or decoction of bark in fever. In Southern Sumatra, the bark is chewed at the first sign of sprue. It is chewed as a substitute for pan by Nagas. ${ }^{[2]}$ This plant contains sesquiterpene 'zaluzanin D', which is a potent antifungal agent. ${ }^{[3]}$

Tribal groups residing in the Western Ghat region of Chikmagalur district, Karnataka State, use the leaf extract for septic wounds, in treating jaundice fever and rheumatic pains (Personal communication).

A review of the literature revealed that the wound-healing property of this plant has not been subjected to scientific evaluation. This paper reports the wound-healing property of this rare plant.

\section{Materials and methods}

\section{Plant material}

Leaves of Vernonia arborea were collected from the Western Ghat range of Chikmagalur district of Karnataka State, during December 2003 and identified by the first author. The voucher specimens (BKM-533, BKM-554) were deposited in the Kuvempu University herbaria.

\section{Extraction}

Leaves were shade dried and powdered mechanically. About $250 \mathrm{~g}$ of powder was subjected to soxhlet extraction with $70 \%$ methanol for about $48 \mathrm{~h}$. The extract was filtered and concentrated in vacuum under reduced pressure using a rotary flash evaporator (Buchi, Flawil, Switzerland) and dried in a desiccator (yield $22.6 \% \mathrm{w} / \mathrm{w}$ ).

For aqueous extract, 250g of powdered leaves was macerated with $1000 \mathrm{ml}$ of distilled water for three days with intermittent stirring, filtered and concentration (yield 18\% w/ w). Both the extracts were subjected to preliminary phytochemical tests. ${ }^{[4]}$ 


\section{Drug formulations}

Two types of drug formulations were prepared from each of the extracts. For topical administration, 5\% w/w ointment was prepared in $2 \%$ sodium alginate. For oral administration, $30 \mathrm{mg} / \mathrm{ml}$ of aqueous and methanol suspensions of leaf extracts were prepared in $1 \%$ gum tragacanth.

\section{Animals}

Swiss Wistar strain rats of either sex weighing 150-200 g were procured from the National College of Pharmacy, Shimoga, Karnataka and were maintained at standard housing conditions. The animals were fed with a commercial diet (Hindustan Lever Ltd., Bangalore, India) and water ad libitum during the experiment. The study was permitted by the Institutional Animal Ethics Committee, National College of Pharmacy, Shimoga. Acute toxicity study was conducted for both the extracts by the stair-case method. ${ }^{[5]}$

\section{Wound-healing activity}

Excision, incision and dead space wound models were used to evaluate the wound-healing activity.

\section{Excision wound}

The rats were inflicted with excision wounds as described by Morton and Malone (1972) $)^{[6]}$ under light ether anaesthesia. A circular wound of about 500 sq. mm was made on depilated ethanol sterilized dorsal thoracic region of the rats. The animals were divided into four groups of six each. The animals of group I were left untreated and considered as the control, group II served as reference standard and treated with $1 \% \mathrm{w} / \mathrm{w}$ framycetin sulphate cream (FSC), animals of group III and IV were treated with $50 \mathrm{mg}$ of ointment prepared from aqueous and methanol leaf extract of Vernonia arborea. The ointment was topically applied once a day, starting from the day of the operation, till complete epithelialisation. The parameters studied were wound closure and epithelialisation time. The wounds were traced on $\mathrm{mm}^{2}$ graph paper on days $3,6,9,12$, 15 and 18 and thereafter on alternate days until healing was complete. The percentage of wound closure was calculated. The period of epithelialisation was calculated as the number of days required for falling of the dead tissue remnants of the wound without any residual raw wound.

\section{Incision wound}

In incision wound model, $6 \mathrm{~cm}$ long paravertebral incisions were made through the full thickness of the skin on either side of the vertebral column of the rat as described by Ehrlich and Hunt et al..$^{[7 \mid}$ The wounds were closed with interrupted sutures of $1 \mathrm{~cm}$ apart. The animals were divided into four groups of six animals each. The animals of group I were left untreated and considered as the control, the group II served as reference standard and received 1\% w/w framycetin sulphate cream (FSC) ointment, animals in groups III and IV were treated with $50 \mathrm{mg}$ of ointment prepared from aqueous and methanol leaf extract. The ointment was topically applied once in a day. The sutures were removed on the $8^{\text {th }}$ post wound day. The skin breaking strength of the wounds was measured on the 10th day as described in the method of Lee $e t$ al. ${ }^{[8]}$

\section{Dead space wound}

The animals were divided into three groups of 6 rats in each group. Group I served as the control, which received $1 \mathrm{ml}$ of $1 \%$ gum tragacanth $/ \mathrm{kg}$, b.w., p.o. The animals of group II and III received oral suspensions of aqueous and methanol leaf extracts respectively (30 mg/kg, b.w., p.o.). Under light ether anaesthesia, dead space wounds were created by subcutaneous implantation of sterilized cylindrical grass piths $(2.5 \mathrm{~cm} \times 0.3 \mathrm{~cm})$, one on either side of the dorsal paravertebral surface of the rat. ${ }^{[9]}$ The granulation tissues formed on the grass piths were excised on the $10^{\text {th }}$ post wounding day and the breaking strength was measured. Simultaneously, granulation tissue so harvested was subjected to hydroxyproline estimation following the method of Woessner et al., ${ }^{[10]}$ and histopathological study to evaluate the effect of the extracts on collagen formation.

\section{Statistical analysis}

The data were subjected to ANOVA followed by Dunnett's test and the values of $\mathrm{P} \leq 0.001$ were considered statistically significant.

\section{Results}

The $\mathrm{LD}_{50}$ of aqueous and methanol leaf extracts were found to be $300 \mathrm{mg} / \mathrm{kg}$, b.w. One tenth of the dose was selected ${ }^{[5]}$ for the evaluation of wound-healing activity i.e., $30 \mathrm{mg} / \mathrm{kg}$, b.w.

Significant promotion of wound-healing activity was observed in both aqueous and methanol leaf extracts in all the three wound models such as excision, incision and dead space wound. In excision wound model, the mean percentage closure of wound area was calculated on the 3, 6, 9, 12, 15 and 18 post wounding days as shown in Table 1. The methanol leaf extract treated animals showed faster epithelialisation of wound $(17.86 \pm 0.19)$ than the animals treated with aqueous leaf extract $(19.03 \pm 0.59)$. The period of epithelialisation was $16.15 \pm 0.21$ in the case of standard drug $1 \% \mathrm{w} / \mathrm{w}$ framycetin sulphate cream (FSC) ointment.

In incision wound model, methanol and aqueous leaf extract treated animals showed increase in breaking strength (494.41 \pm 4.30$)$, $(463.74 \pm 3.63)$, respectively when compared to the control $(240.46 \pm 3.28)$. The mean breaking strength was also significant in animals treated with standard drug FSC (567.02 \pm 2.12$)$.

In dead space wound model, histological studies of the granulation tissue of the control group of animals showed more aggregation of macrophages with few collagen fibres. [Figure 1] In the case of aqueous leaf extract treated animal groups, moderate collagen deposition, macrophages and fibroblasts were noticed Figure 2 whereas the methanol leaf extract treated animal group evidenced significant increase in collagen deposition showing lesser macrophages and fibroblasts. [Figure 3] Compared to the control group of animals, methanol leaf extract treated animals showed significant increase in dry weight of granulation tissue $(184.46 \pm 0.49)$ and breaking strength (387.72 \pm 3.25$)$ followed by aqueous leaf extract treat ed group of animals. [Table 2] Estimation of hydroxyproline content in the granulation tissue revealed that the animal groups treated with methanol leaf extract had high hydroxyproline content $(2250.00 \pm 0.57)$ followed by the aqueous leaf extract treated group (1979.33 \pm 0.80$)$. However, the control group showed less hydroxyproline content (1398.66士1.02).

\section{Discussion}

Wound healing is a fundamental response to tissue injury 
that results in restoration of tissue integrity, which is due to the synthesis of the connective tissue matrix. Collagen is a major protein of the extracellular matrix and is the component that ultimately contributes to wound strength. Breakdown of collagen liberates free hydroxyproline and its peptides. Measurement of the hydroxyproline could be used as an index for collagen turnover. The data depicted in Table 2 reveal that the hydroxyproline content of the granulation tissue of the animals treated with methanol and aqueous leaf extract was significantly increased when compared to the control group, indicating increased collagen turnover. Increase in breaking strength of granulation tissue of methanol and aqueous leaf

Table 1

Effect of topical application of aqueous and methanol leaf extracts of Vernonia arborea on healing of excision wound model

\begin{tabular}{|c|c|c|c|c|c|c|c|c|}
\hline \multirow[t]{2}{*}{ Group } & \multicolumn{7}{|c|}{ Post wounding days } & \multirow{2}{*}{$\begin{array}{c}\text { Period of } \\
\text { epithelialisation }\end{array}$} \\
\hline & 0-day & 3rd day & 6th day & 9th day & 12th day & 15th day & 18th day & \\
\hline Control & $\begin{array}{c}511.91 \pm 0.46 \\
(0.00)\end{array}$ & $\begin{array}{c}484.53 \pm 1.49 \\
(5.34)\end{array}$ & $\begin{array}{r}404.21 \pm 1.14 \\
(21.03)\end{array}$ & $\begin{array}{r}357.62 \pm 0.58 \\
(30.14)\end{array}$ & $\begin{array}{r}277.85 \pm 0.72 \\
(45.72)\end{array}$ & $\begin{array}{r}191.16 \pm 0.54 \\
(62.65)\end{array}$ & $\begin{array}{r}88.32 \pm 0.50 \\
(82.74)\end{array}$ & $24.29 \pm 0.23$ \\
\hline Standard & $\begin{array}{c}510.00 \pm 1.48^{*} \\
(0.00)\end{array}$ & $\begin{array}{r}407.30 \pm 0.61^{*} \\
(20.13)\end{array}$ & $\begin{array}{r}323.59 \pm 1.31^{*} \\
(36.35)\end{array}$ & $\begin{array}{r}252.37 \pm 0.53^{*} \\
(50.51)\end{array}$ & $\begin{array}{r}136.35 \pm 0.47^{*} \\
(73.26)\end{array}$ & $\begin{array}{c}9.32 \pm 0.44^{*} \\
(98.17)\end{array}$ & $\begin{array}{l}0^{*} \\
(100)\end{array}$ & $16.15 \pm 0.21^{*}$ \\
\hline $\begin{array}{l}\text { Methanol } \\
\text { extract }\end{array}$ & $\begin{array}{c}508.81 \pm 1.51^{*} \\
(0.00)\end{array}$ & $\begin{array}{r}443.20 \pm 1.18^{*} \\
(12.89)\end{array}$ & $\begin{array}{r}331.64 \pm 0.58^{*} \\
(34.82)\end{array}$ & $\begin{array}{r}268.25 \pm 0.55^{*} \\
(47.27)\end{array}$ & $\begin{array}{r}141.40 \pm 0.43^{*} \\
(72.28)\end{array}$ & $\begin{array}{r}18.50 \pm 0.43^{*} \\
(96.36)\end{array}$ & $\begin{array}{l}0^{*} \\
(100)\end{array}$ & $17.86 \pm 0.19^{*}$ \\
\hline One-way & 12.87 & 25.19 & 15.54 & 12.70 & 10.52 & 12.31 & 15.43 & 11.59 \\
\hline ANOVA & $<0.001$ & $<0.001$ & $<0.001$ & $<0.001$ & $<0.001$ & $<0.001$ & $<0.001$ & $<0.001$ \\
\hline
\end{tabular}

Values are expressed as mean $\pm S E M ; d f=3,20 ; n=6$ animals in each group; Numbers in parenthesis indicate percentage of wound contraction; ${ }^{*} \mathrm{P} \leq 0.001$ when compared to control.

\section{Table 2}

Effect of aqueous and methanol leaf extracts of Vernonia arborea on healing of dead space wound model

\begin{tabular}{|c|c|c|c|}
\hline Group & $\begin{array}{l}\text { Granulation tissue dry weight } \\
(\mathrm{mg} / 100 \mathrm{~g})\end{array}$ & $\begin{array}{l}\text { Breaking strength } \\
\text { (g) }\end{array}$ & $\begin{array}{l}\text { Hydroxyproline } \\
(\mathrm{mg} / 100 \mathrm{~g})\end{array}$ \\
\hline Control $(1 \mathrm{ml}$ of $1 \%$ gum tragacanth $/ \mathrm{kg}$, b.w.) & $87.94 \pm 0.61$ & $230.46 \pm 2.57$ & $1398.66 \pm 1.02$ \\
\hline Methanol extract & $184.46 \pm 0.49^{*}$ & $387.72 \pm 3.25^{\star}$ & $2250.00 \pm 0.57^{*}$ \\
\hline One-way & 11.02 & 10.89 & 15.03 \\
\hline
\end{tabular}

Values are expressed as mean $\pm \mathrm{SEM} ; \mathrm{df}=2,15 ; \mathrm{n}=6$ animals in each group; ${ }^{*} \mathrm{P} \leq 0.001$ when compared to control.

Figure 1. Histological section of granulation tissue of control animal showing more macrophages (arrows). (H\& E, 100X)

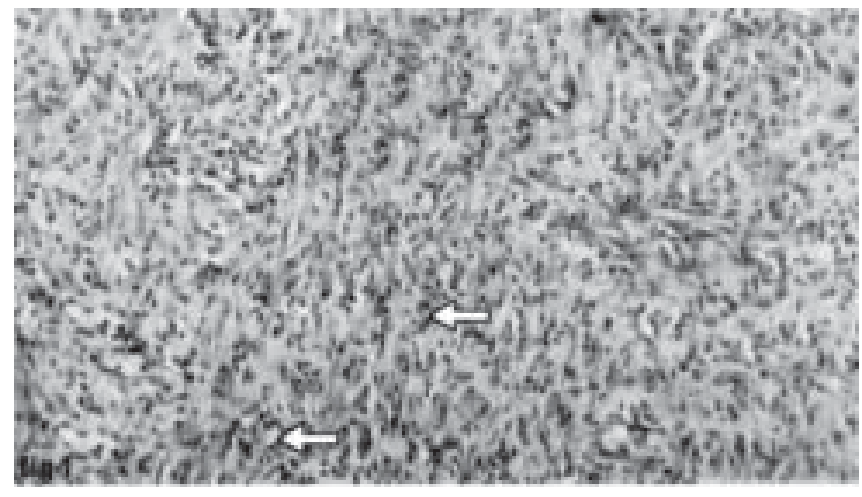

Figure 2. Histological section of granulation tissue of the aqueous leaf extract treated animal showing moderate collagen deposition. $(H \& E, 100 X)$

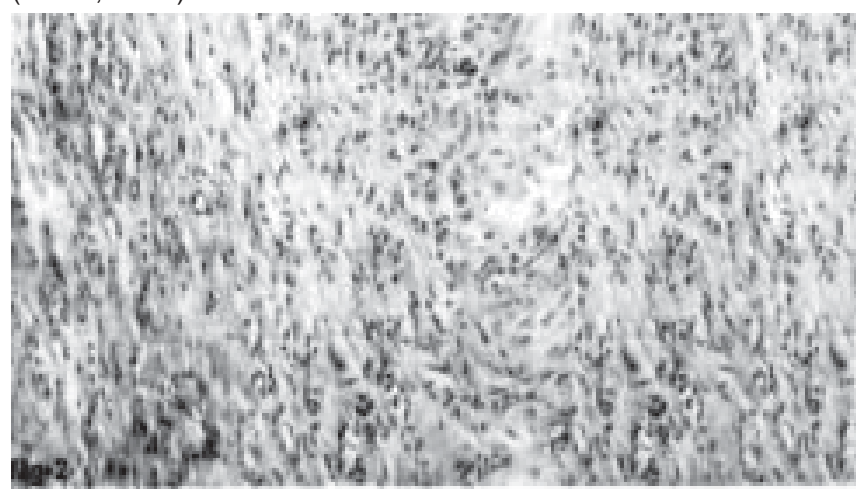


Figure 3. Histological section of granulation tissue of the animal treated with methanol leaf extract of Vernonia arborea showing increased collagenation (arrows) and lesser macrophages and fibroblasts. (H \& E, 100X).

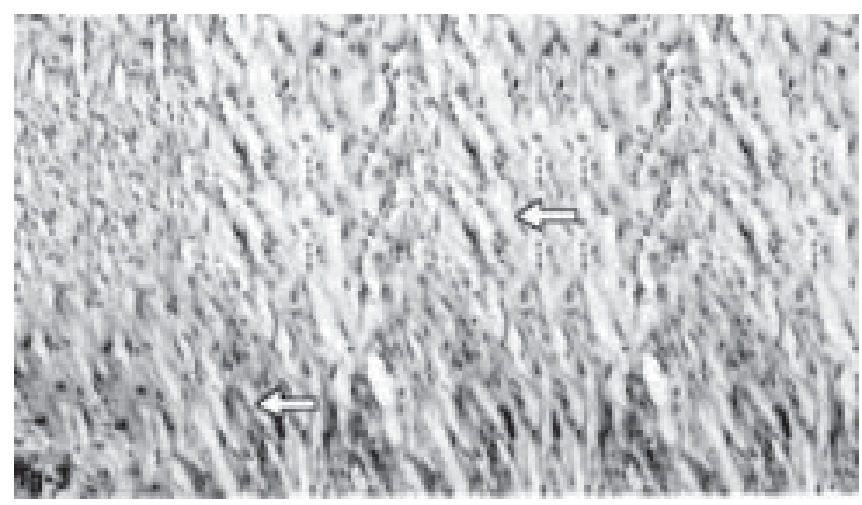

extract treated animals indicated the enhanced collagen maturation by increased crosslinking. In addition, increase in dry granulation tissue weight also indicated the presence of higher protein content. ${ }^{[11]}$ In the present investigation, preliminary phytochemical analysis of aqueous leaf extract revealed the presence of flavonoids, saponins, tannins and glycosides whereas methanol extract showed positive test to flavonoids, saponins, tannins, glycosides, sesquiterpenes and triterpenoids. Flavonoids are known to reduce lipid peroxidation not only by preventing or slowing the onset of cell necrosis but also by improving vascularity. Hence, any drug that inhibits lipid peroxidation is believed to increase the viability of collagen fibrils by increasing the strength of collagen fibres, increasing the circulation, preventing the cell damage and by promoting the DNA synthesis. ${ }^{[12]}$ Tannins, ${ }^{[13]}$ flavonoids, ${ }^{[14]}$ triterpenoids $^{[15]}$ and sesquiterpenes ${ }^{[16]}$ are also known to promote the wound-healing process mainly due to their astringent and antimicrobial property, which seems to be responsible for wound contraction and increased rate of epithelialisation. The sesquiterpene lactones are known to possess antioxidant property, ${ }^{\left[17,{ }^{18]}\right.}$ which may also contribute to the wound-healing process. Thus, wound-healing potency of Vernonia arborea may be attributed to the phytoconstituents present in it, which may be either due to their individual or additive effect that fastens the process of wound healing. Between the two extracts studied, the methanol leaf extract was found to possess better wound-healing property. Which component(s) of the extract is responsible for this effect, however, was not investigated. Further phytochemical studies are in progress where the methanol extract will be subjected to further fractionation and purification to identify and to isolate the active compound(s) responsible for these pharmacological activities. The present findings provide scientific evidence to some of the ethnomedicinal properties of Vernonia arborea.

\section{Acknowledgments}

The authors are very grateful to the National Educational Society, Shimoga, Prof. T.S. Ramakumar, Principal, S.R.N.M.N. College of Applied Sciences, Shimoga, Dr. Y.N. Manohara, Principal, National College of Pharmacy, Shimoga and Dr. V. Krishna, Department of Biotechnology, Kuvempu University, for providing necessary facilities to carry out this work.

\section{References}

1. Gamble JS. Flora of the Presidency of Madras. Calcutta: Botanical Survey of India; 1936.

2. Chopra RN, Nayar SL, Chopra IC. Glossary of Indian Medicinal Plants. C.S.I.R. Publications; New Delhi; 2003.

3. Krishna Kumari GN, Masilamani S, Ganesh MR, Aravind S, Sridar SR. Zaluzanin D: A fungistatic sesquiterpene from Vernonia arborea. Fitoterapia 2003;74:47982.

4. Kokate CK, Purohith AP, Gokhale SB. Pharmacognosy. Pune: Nirali Prakashan; 1990.

5. Jalalpure SS, Patil MB, Prakash NS, Hemalatha K, Manvi FV. Hepatoprotective activity of fruits of Piper longum L. Indian J Pharm Sci 2003;65:363-6.

6. Morton JJ, Malone MH. Evaluation of vulnerary activity by an open wound procedure in rats. Arch Int Pharmacodyn Ther 1972;196:117-26.

7. Ehrlich HP, Hunt TK. Effect of cortisone and vitamin A on wound healing. Ann Surg 1968;167:324-8.

8. Lee KH. Studies on mechanism of action of salicylates II. Retardation of wound healing by aspirin. J Pharm Sci 1968;57:1042-3.

9. Turner RA. Screening Methods in Pharmacology. New York: Academic Press; 1965.

10. Woessner JF. The determination of hydroxyproline in tissue and protein samples containing small proportions of this imino acid. Archiv Biochem Biophys 1961;93: 440-7.

11. Azad S. Essentials of surgery. Hyderabad, India: PARAS Medical Publishers; 2002.

12. Getie M, Gebre Mariam T, Reitz R, Neubert RH. Evaluation of the release profiles of flavonoids from topical formulations of the crude extract of the leaves of Dodonea viscosa (Sapindaceae). Pharmazie 2002:57:320-2.

13. Ya C, Gaffney SH, Lilley TH, Haslam E. Carbohydrate-polyphenol complexation. In: Hemingway RW, Karchesy JJ, eds. Chemistry and significance of condensed tannins. New York: Plenum Press; 1988.

14. Tsuchiya H, Sato M, Miyazaki T, Fujiwara S, Tanigaki S, Ohyama M, et al. Comparative study on the antibacterial activity of phytochemical flavanones against methicillin-resistant Staphylococcus aureus. J Ethnopharmacol 1996;50:27-34.

15. Scortichini M, Pia Rossi M. Preliminary in vitro evaluation of the antimicrobial activity of terpenes and terpenoids towards Erwinia amylovora (Burrill). J Appl Bacteriol 1991;71:109-12.

16. Goren N, Woerdenbag H, Bozok-Johansson C. Cytotoxic and antibacterial activities of sesquiterpene lactones isolated from Tanacetum praeteritum subsp. praeteritum. Planta Med 1996;62:419-22.

17. Kubo I, Chaudhuri SK, Kubo Y, Sanchez Y, Ogura T, Saito T, et al. Cytotoxic and antioxidative sesquiterpenoids from Heterotheca inuloides. Planta Med 1996;62:427-30.

18. Haraguchi H, Saito T, Ishikawa H, Sanchez Y, Ogura T, Kubo I. Inhibition of lipid peroxidation by sesquiterpenoid in Heterotheca inuloides. J Pharm Pharmacol 1996;48:441-3. 